\title{
GENUS LAGOMYS.-Geofr.
}

\author{
DENTAL FORMULA. \\ Incisive $\frac{2-2}{1-1}$ Canine $\frac{0-0}{0-0} ;$ Molar $\frac{5-5}{5-5}=26$.
}

Teeth and toes similar to those of the genus Lepus, upper incisors in pairs, two in front and two immediately behind them, the former large and the latter small.

Ears moderate ; eyes, round ; hind legs not much longer than fore legs ; fur under the feet; no tail ; mammæ four or six ; clavicles nearly perfect.

Native of cold and Alpine regions. They lay up stores for winter provision which is never done by the true hares. They have a call-note resembling that of some species of Tamice.

The name of this sub-genus, Lagomys, is derived from the Greek words

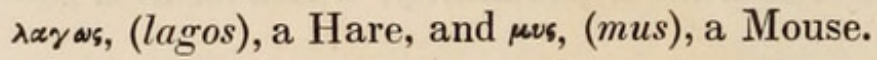

Four species of this genus are described; one, the Pika, exists in the northern mountains of the Old World, one in Mongolian Tartary, one in the south eastern parts of Russia, and one in the Rocky Mountains of North America.

LAGOMYS PRIN CEPS.-RichaRdSON.

Little-Chief Hare.

PLATE LXXXIII.-MALES.

L. Ecaudatus, fuscus, latere pallidior, subtus griseus, capite brevi ; auriculis rotundatis.

CHARACTERS.

Tailless; colour blackish brown, beneath gray; head short and thick; ears rounded. 


\section{$2 \mathrm{BHL}$ Biodiversity Heritage Library}

Audubon, John James and Bachman, John. 1851. "Genus Lagomys." The quadrupeds of North America 2, 244-244. https://doi.org/10.5962/p.322430.

View This Item Online: https://www.biodiversitylibrary.org/item/108514

DOI: https://doi.org/10.5962/p.322430

Permalink: https://www.biodiversitylibrary.org/partpdf/322430

\section{Holding Institution}

Duke University Libraries (archive.org)

\section{Sponsored by}

Duke University Libraries

\section{Copyright \& Reuse}

Copyright Status: Not provided. Contact Holding Institution to verify copyright status.

This document was created from content at the Biodiversity Heritage Library, the world's largest open access digital library for biodiversity literature and archives. Visit BHL at https://www.biodiversitylibrary.org. 